\title{
Absorbed Dose Rate Produced by Natural Uranium as a Function of Depth in Tissue
}

\author{
PHILLIP PLATO \\ Department of Environmental and Industrial Health, School of Public Health, \\ The University of Michigan, Ann Arbor, MI 48109, U.S.A.
}

(Received 21 November 1977; in revised form 26 July 1978)

\begin{abstract}
Slabs of natural and depleted uranium are used routinely to calibrate personal dosimeters and radiation survey instruments for beta radiation. However, little information is available on the absorbed dose rate produced by a uranium slab as a function of depth in matter. In this study, an extrapolation chamber was used to measure the dose rate produced by natural uranium at a variety of depths in a tissue-equivalent material (Mylar). The dose rate decreases from $11,900 \mathrm{mrad} \mathrm{h}^{-1}$ at the surface of the uranium to $229 \mathrm{mrad} \mathrm{h}^{-1}$ at a depth of $7 \mathrm{mg} \mathrm{cm}^{-2}$ and to about $60 \mathrm{mrad} \mathrm{h}^{-1}$ at a depth of about $250 \mathrm{mg} \mathrm{cm}^{-2}$.
\end{abstract}

\section{INTRODUCTION}

SLABS of natural and depleted uranium are used routinely to calibrate personal dosimeters and radiation survey instruments for beta radiation. Since beta particles have a relatively short range in matter, the thickness of materials used to construct a personal dosimeter (paper wrapping, plastic holder, filters) has a significant effect on the response of the dosimeter. Therefore, the use of uranium to calibrate personal dosimeters for beta radiation requires accurate knowledge of the absorption in the materials used.

Although uranium is widely used as a calibration source, relatively little information is available on the absorbed dose rate as a function of depth in matter. In the 1940s, LEAP and WHIPPLE ${ }^{(1)}$ measured the dose rate (in units of mrep $\mathrm{h}^{-1}$ ) at several depths between 5 and $30 \mathrm{mg} \mathrm{cm}^{-2}$ of Lucite and compared their data to similar measurements made by others in the 1930s. These data are incomplete and difficult to obtain since most of the results were prepared as internal reports for various national laboratories.

BORTNER ${ }^{(2)}$ found the dose rate in air produced by natural uranium to be $14.4 \mathrm{esu} \mathrm{cm}^{-3} \mathrm{~h}^{-1}$ at the surface and $0.240 \mathrm{esu} \mathrm{cm}^{-3} \mathrm{~h}^{-1}$ (approx $236 \mathrm{mrad} \mathrm{h}^{-1}$ in tissue) at a depth of $6.9 \mathrm{mg} \mathrm{cm}^{-2}$ in polystyrene. O'Brien et al ${ }^{(3)}$ calculated and measured the dose rate produced by natural uranium at various depths in aluminum and lead. They found the dose rate in air to be 0.238 esu $\mathrm{cm}^{-3} \mathrm{~h}^{-1}$ at a depth of $6.3 \mathrm{mg}$ $\mathrm{cm}^{-3}$ in aluminum. They also demonstrated the effect of materials used to construct an extrapolation chamber on dose rate measurements.

In the United States, the most commonly quoted ${ }^{(4)}$ dose rate for uranium is $233 \mathrm{mrad} \mathrm{h}^{-1}$ at a depth of $7 \mathrm{mg} \mathrm{cm}$. The objective of this study is to measure accurately the dose rate produced by natural uranium at a variety of depths in a tissue-equivalent material.

\section{METHODS AND MATERIALS}

Absorbed dose rate measurements were made with an extrapolation chamber built at The University of Michigan. Figure 1 shows a cross-sectional diagram of the chamber. The uranium slab is a disc, $10.7 \mathrm{~cm}$ in diameter and $0.6 \mathrm{~cm}$ thick, set in a larger Lucite disc. Dose rate measurements are made with the uranium positioned just above the high-voltage electrode made of $1.78 \mathrm{mg} \mathrm{cm}^{-2}$ Mylar aluminized on one side (the side facing the guard and collecting electrodes). Additional layers of Mylar are placed between the uranium and the high-voltage electrode to simulate various thicknesses of tissue.

Mylar (polyethyleneterapthtlate, $\mathrm{C}_{5} \mathrm{H}_{4} \mathrm{O}_{2}$ ) and Lucite (polymethylmethacrylate, $\mathrm{C}_{5} \mathrm{H}_{8} \mathrm{O}_{2}$ ) are used to approximate tissue $\left(\mathrm{C}_{5} \mathrm{H}_{40} \mathrm{O}_{18} \mathrm{~N}\right)$ since the effective atomic numbers of these materials are similar as determined by ${ }^{(5)}$ :

$$
Z_{\text {eff }}=\frac{N_{1} Z_{1}^{2}+N_{2} Z_{2}^{2}+\ldots}{N_{1} Z_{1}+N_{2} Z_{2}+\cdots}
$$

where $N$ is the number of atoms per cubic centimeter of an element with atomic number $Z$. The effective atomic numbers of Mylar, Lucite, and tissue are 6.24, 5.85 , and 6.43 , respectively, as calculated from equation (1). Moreover, the mass collision stopping powers for Mylar, Lucite, and tissue vary by only about $10 \%$ for beta particles in the $0.1-2 \mathrm{MeV}$ range common to uranium. ${ }^{(6)}$

The spacing between the high voltage and collecting electrodes was varied from approx 0.11 to $0.16 \mathrm{~cm}$. A 22-V battery was used to keep a potential difference between the high-voltage and collecting electrodes. Saturation curves showed that this voltage resulted in the collection of all charges produced between the electrodes at large spacings and caused no distortion of the high-voltage electrode at small spacings. 


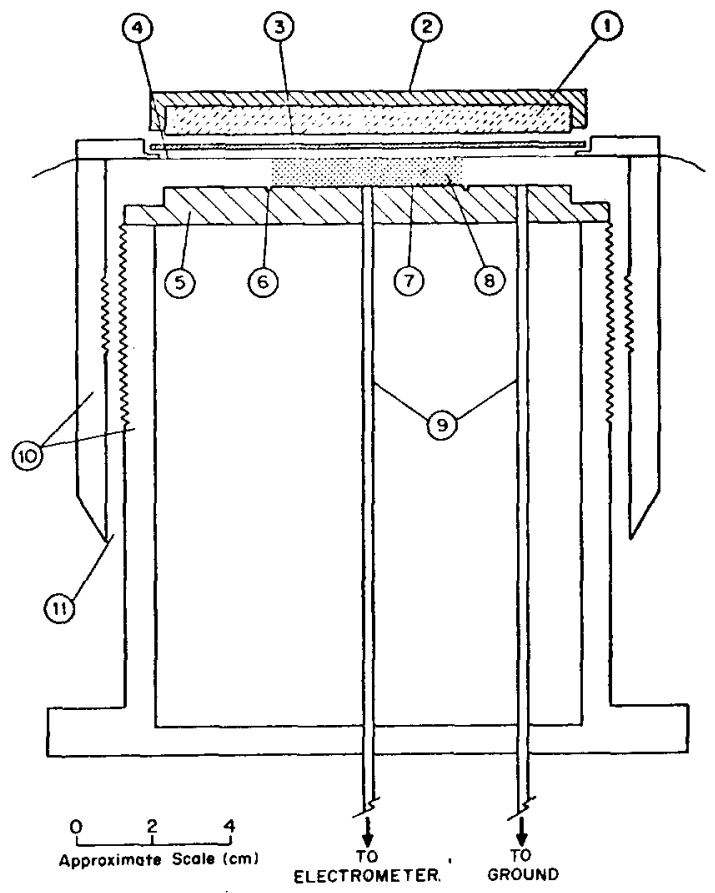

FIG. 1. Cross-sectional diagram of The University of Michigan extrapolation chamber: 1. circular slab of natural uranium set in Lucite; 2 circular piece of Lucite used to hold the uranium slab; 3. Mylar discs used to stimulate varying thicknesses of tissue; 4 . high-voltage electrode made of $1.78 \mathrm{mg} \mathrm{cm}^{-2}$ Mylar aluminized on the side facing the guard and collecting electrodes; 5 . Lucite disc aluminized on the side facing the high-voltage electrode to form the guard and the collecting electrodes; 6 . groove cut through aluminum coating to separate the annular guard electrode from the circular collecting electrode; 7. circular collecting electrode; 8 . sensitive air volume between high-voltage and collecting electrodes; 9 . coaxial cables; 10 . threaded brass cylinders that form the side of the chamber and permit the distance between the high-voltage and collecting electrodes to be varied; 11. micrometer scale to measure the relative spacing between the high-voltage and collecting electrodes.

Charges produced in the sensitive air volume of the extrapolation chamber (the volume defined by the area of the collecting electrode and the distance between the high-voltage and collecting electrodes) are collected and transmitted through a coaxial cable to an amplifier and finally to a Cary Model 31 Vibrating Reed Electrometer, manufactured by the Applied Physics Corporation of Monrovia, California. The voltage drop measured across a high-value calibrated resistor is used to measure the current originating from the sensitive air volume (No. 8 in Fig. 1) of the extrapolation chamber.

The surface of the uranium is polished to remove oxidation products before each measurement is made to insure that Mylar is the only absorbing material between the uranium and the sensitive air volume. The oxidation layer, which is visible within a few hours after the uranium is polished, is too thin to influence dose rate measurements at depths greater than a few $\mathrm{mg} \mathrm{cm}^{-2}$ of Mylar, but it can become a significant absorber as the depth of Mylar approaches zero.

The spacing between the high-voltage and collecting electrodes is varied by rotating the threaded outer brass cylinder of the chamber. A micrometer scale (No. 11 in Fig. 1) is located on the side of the threaded inner brass cylinder of the chamber. If the current, $i$, measured with the electrometer is plotted as a function of the micrometer scale setting, $y$, a straight line is expected, provided that the electrode spacing is kept small. The slope of the straight line, $\mathrm{d} i / \mathrm{d} y$ in units of amperes per centimeter, is used to calculate the absorbed dose rate in the sensitive air volume by:

$$
\dot{D}_{\mathrm{air}}=\left(3.6 \times 10^{11}\right) \frac{\bar{W} \mathrm{~d} i / \mathrm{d} y}{a \cdot \rho}
$$

where:

$$
\begin{aligned}
\dot{D}_{\text {air }}= & \text { absorbed dose rate in the air of the } \\
& \text { sensitive volume }\left(\mathrm{mrad}^{-1}\right) \\
a= & \text { area of the collecting electrode } \\
& \left(\mathrm{cm}^{2}\right) \\
\bar{W}= & \text { average energy expended by elec- } \\
& \text { trons in air per ion pair formed } \\
& (\mathrm{eV} / \text { ion pair }) ; \text { assumed to be } \\
& 33.73 \pm 0.15 \mathrm{eV} / \text { ion pair }^{(7)} \\
\rho= & \text { actual density of air }\left(\mathrm{g} \mathrm{cm}^{-3}\right) \text { cor- } \\
& \text { rected for the temperature and } \\
& \text { pressure at the time of measure- } \\
& \text { ment al constants } \\
3.6 \times 10^{11}= & \text { combination of all con the units of } \\
& \text { required to balance the } \\
& \text { equation }(2) .
\end{aligned}
$$

A micrometer scale setting, $y$, is related to an actual electrode spacing, $d$, by $y=d+x_{0}$ where $x_{0}$ corrects for the difference between $y$ and $d$. An accurate determination of $x_{0}$ is not necessary, since it is the change in $i$ with respect to a change in $y, \mathrm{~d} i / \mathrm{d} y$, that is used in equation (2) to calculate absorbed dose rates. The approximate value of $x_{0}$ was found to be $-0.082 \mathrm{~cm}$.

The absorbed dose rate in tissue is related to the absorbed dose rate in air by the relative stopping power for tissue which is assumed to be $1.13 .^{(8)}$ Thus,

$$
\dot{D}_{\text {iissue }}=1.13 \dot{\mathrm{D}}_{\mathrm{air}}
$$

where $\dot{D}$ represents absorbed dose rate in units of $\operatorname{mrad} \mathrm{h}^{-1}$.

The proper use of an extrapolation chamber has been discussed in detail by others. ${ }^{(9.10)}$ Use of an extrapolation chamber to measure dose rates in tissue requires that two fixed quantities be known accurately: the area of the collecting electrode and the resistance of the high-value resistor. The area of the collecting electrode in The University of Michigan extrapolation chamber was determined by measuring its diameter beginning and ending with the center of the $0.01 \mathrm{~cm}$ wide groove (No. 6 in Fig. 1) that separates the collecting electrode from the guard electrode. 
TABLE 1. Typical set of data used to determine the absorbed dose rate produced by natural uranium at a specific depth in a tissue-equivalent material (Mylar)

\begin{tabular}{cccccc}
\hline $\begin{array}{c}\text { Approximate } \\
\text { electrode } \\
\text { spacing } \\
d(\mathrm{~cm})\end{array}$ & $\begin{array}{c}\text { Micrometer } \\
\text { scale } \\
\text { setting }\end{array}$ & \multicolumn{3}{c}{$\begin{array}{c}\text { Voltage measured } \\
\text { with electrometer }\end{array}$} & Current \\
\cline { 3 - 5 } & $y(\mathrm{~cm})$ & $(+)$ & $(-)$ & Average & $i(\mathrm{~A})$ \\
\hline 0.11 & 0.0254 & 0.335 & 0.475 & 0.4050 & $4.311 \times 10^{-14}$ \\
0.12 & 0.0381 & 0.382 & 0.520 & 0.4510 & 4.800 \\
0.13 & 0.0508 & 0.435 & 0.568 & 0.5015 & 5.338 \\
0.14 & 0.0635 & 0.482 & 0.615 & 0.5485 & 5.838 \\
0.16 & 0.0762 & 0.530 & 0.663 & 0.5965 & 6.349 \\
\hline
\end{tabular}

$\mathrm{d} i / \mathrm{d} y=40.27 \times 10^{-14} \mathrm{~A} \mathrm{~cm}^{-1}$

$\dot{D}_{\text {air }}=214.8 \mathrm{mrad} \mathrm{h}^{-1}$

$D_{\text {tissue }}=242.8 \mathrm{mrad} \mathrm{h}^{-1}$.

thickness of added Mylar $=1.61 \mathrm{mg} \mathrm{cm}^{-2}$

thickness of high-voltage electrode $=1.78 \mathrm{mg} \mathrm{cm}^{-2}$

total depth in tissue (Mylar) $=3.39 \mathrm{mg} \mathrm{cm}^{-2}$

temperature $=291^{\circ} \mathrm{K}$

pressure $=717.8 \mathrm{~mm} \mathrm{Hg}$

resistance $=0.9395 \times 10^{12} \Omega$.

The diameter was measured with a Bendix Optical Countour Projector, the calibration of which is traceable to the U.S. National Bureau of Standards. An average of four measurements of the diameter resulted in a calculated area of $19.8365 \pm 0.0017 \mathrm{~cm}^{2}$ (the uncertainty term represents $2 \sigma$ ). Two high-value resistors were used for the measurements reported in this paper. Both resistors were calibrated at $1 \mathrm{~V}$ by the U.S. National Bureau of Standards to within $\pm 0.5 \%$.

\section{RESULTS}

Table 1 shows a set of typical data used to measure the absorbed dose rate produced by the slab of natural uranium at a particular depth in tissue (simulated with Mylar). With the polarity of the high-voltage electrode positive with respect to the collecting and guard electrodes, the voltage drop across the high-value resistor was made at five different electrode spacings. The polarity across the electrodes was then reversed, and voltage measurements were repeated at the five electrode spacings. An average voltage drop was calculated for each electrode spacing, and each average voltage was divided by the resistance of the high-value resistor to calculate the current, $i$ in equation (2), originating from the sensitive air volume. The five current values were plotted as shown in Fig. 2 and a least-squares straight line was fitted to the data to confirm that a linear relationship existed between current and electrode spacing. Finally, the slope, $\mathrm{d} i / \mathrm{d} y$, of the line shown in Fig. 2 was calculated and related to the absorbed dose rate in tissue, $\dot{D}_{\text {tissue, }}$ with equations (2) and (3).

Five sets of measurements, similar to those shown in Table 1 and Fig. 2, were made at each of 12 depths in Mylar. These depths ranged from $0.00 \mathrm{mg} \mathrm{cm}^{-2}$ (the high-voltage Mylar electrode was removed and the uranium itself was used as the high-voltage electrode) to $248.33 \mathrm{mg} \mathrm{cm}^{-2}$. The current produced by irradiation of the The University of Michigan extra- polation chamber was too small to permit reproducible measurements of dose rates at depths greater than about $250 \mathrm{mg} \mathrm{cm} \mathrm{cm}^{-2}$. The average dose rates among the five replicate sets of measurements at each depth in Mylar are shown in Table 2 together with an estimate of the total uncertainty associated with each average dose rate. These uncertainty values were calculated by combining, in quadrature, the uncertainty among the five replicate measurements (generally about $2.5 \%$ ), the uncertainty associated with the area of the collecting electrode (negligible), the uncertainty associated with the high-value resistor $(0.5 \%)$, and the uncertainty associated with $\widetilde{W}(0.4 \%)$. No uncertainty term is available for the relative stopping power for tissue, assumed to be 1.13 in equation (3). The uncertainty associated with the measured thickness of each layer of Mylar used is assumed to be negligible.

The data shown in Table 2 are plotted in Fig. 3 without the associated uncertainty ranges.

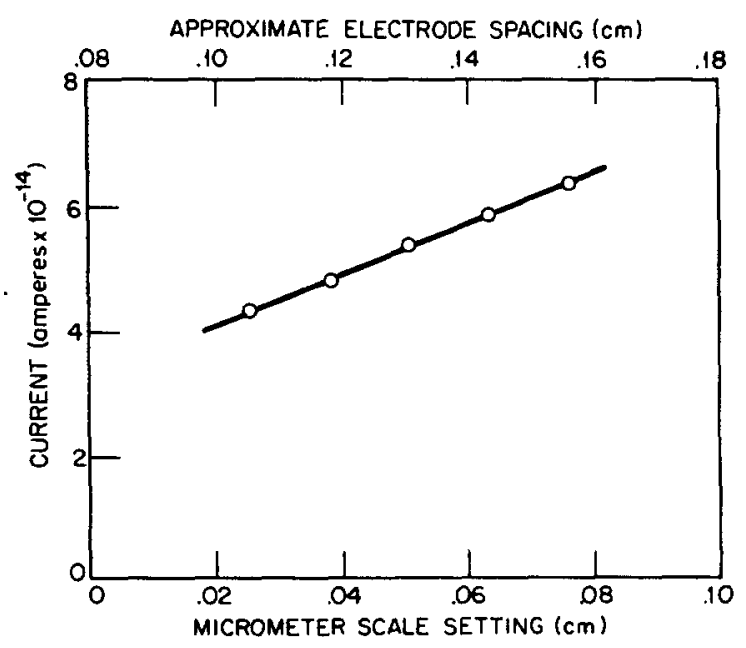

FIG. 2. Variation in current as a function of micrometer scale setting and approximate electrode spacing (data from Table 1). 
TABL: 2. Absorbed dose rate produced by natural uranium as a function of depth in a tissue-equivalent material (Mylar)

\begin{tabular}{cc}
$\begin{array}{c}\text { Total depth } \\
\left(\mathrm{mg} \mathrm{cm}^{-2}\right)\end{array}$ & $\begin{array}{c}\text { Absorbed dose rate and } \\
\text { estimated total uncertainty } \\
\left(\mathrm{mrad} \mathrm{h}^{-1}\right)\end{array}$ \\
\hline 0.00 & $11,860 \pm 428$ \\
1.78 & $1.778 \pm 43$ \\
2.63 & $498.4 \pm 5.9$ \\
3.39 & $240.6 \pm 5.0$ \\
5.00 & $234.8 \pm 4.9$ \\
6.61 & $229.9 \pm 5.2$ \\
8.78 & $223.5 \pm 6.6$ \\
12.27 & $215.0 \pm 5.1$ \\
22.76 & $202.5 \pm 6.6$ \\
33.25 & $190.4 \pm 4.7$ \\
100.40 & $131.7 \pm 3.7$ \\
248.33 & $60.2 \pm 5.1$ \\
\hline
\end{tabular}

\section{DISCUSSION}

Figure 3 shows that the absorbed dose rate in Mylar produced by natural uranium decreases rapidly within the first $3.5 \mathrm{mg} \mathrm{cm}-2$ due to the absorption of alpha particles of various energies emitted by uranium and its daughters. From about 3.5 to $9 \mathrm{mg}$ $\mathrm{cm}^{-2}$. the dose rate decreases exponentially with depth. Interpolation within this depth range shows a dose rate of $228.8 \mathrm{mrad} \mathrm{h}^{-1}$ (properly rounded to $229 \mathrm{mrad} \mathrm{h}^{-1}$ ) at $7.00 \mathrm{mg} \mathrm{cm}^{-2}$, about $2 \%$ less than the commonly quoted value of $233 \mathrm{mrad} \mathrm{h}^{-1}$.

At depths greater than $9 \mathrm{mg} \mathrm{cm}^{-2}$, the dose rate also decreases exponentially with depth but with a different function than that between 3.5 and $9 \mathrm{mg}$ $\mathrm{cm}^{-2}$. This change in the dose rate function is probably due to the penetration of some high energy $(4.7-7.7 \mathrm{MeV})$ alpha particles to depths between 3.5 and $7 \mathrm{mg} \mathrm{cm}^{-2}$. Beta particles and gamma rays with several different energies penetrate to depths greater than $9 \mathrm{mg} \mathrm{cm}^{-2}$.

WHITTON ${ }^{(1)}$ conducted an extensive study of epidermal thicknesses at various body sites. She found the averate epidermal thickness to vary from $4 \mathrm{mg}$ $\mathrm{cm}^{-2}$ for the head and trunk, to $40 \mathrm{mg} \mathrm{cm}^{-2}$ for the palmar surface of the hands. Based on her measurements. she recommends that personal skin dosimeters have window thicknesses of 3,6 , and $30 \mathrm{mg} \mathrm{cm}^{-2}$,

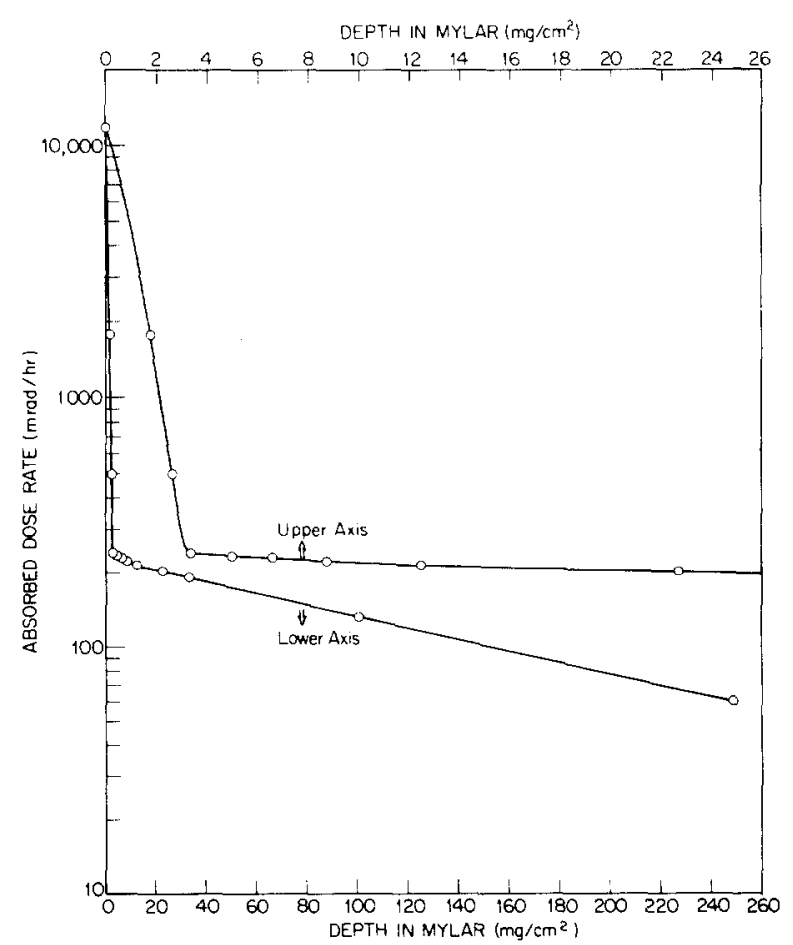

Fig. 3. Absorbed dose rate as a function of depth in Mylar (data from Table 2). 
depending on the part of the body to be monitored. Figure 3 of this paper shows that natural uranium is a poor source to calibrate a skin dosimeter with a window thickness of $3 \mathrm{mg} \mathrm{cm}{ }^{-2}$ because alpha particles penetrate to this depth. From about 3.5 to $9 \mathrm{mg}$ $\mathrm{cm}^{-2}$ the influence of alpha particles is observable but slight.

Acknowledgements - - The author wishes to express his gratitude to Dr G. Hoyt WHiPPLE and Mr Christos KANeLLITSAS for their valuable assistance throughout this study.

\section{REFERENCES}

1. LEAP H. E. and Whipple G. H. HW-11379, Hanford Works (Oct. 1948).
2. BORTNER T. E. ORNL-740, Oak Ridge National Laboratory (October 1950).

3. O'Brien K., Samson S., Sanna R., and Mclaughlin J. E. Nucl. Sci. Engng 18, 90 (1964).

4. Radiological Health Handbook, p. 204. U.S. Department of Health, Education, and Welfare. Washington, D.C. (1970).

5. Evans R. D. The Atomic Nucleus p. 631, McGraw-Hill New York (1955).

6. Pages L., Bertel E., Joffre $H$. and Sklavenitis L. Atom. Data 4, no. 1 (March 1972).

7. U.S. National Bureau of Standards Handbook 85, p. 11. U.S. Government Printing Office, Washington D.C. (March 1964).

8. Report of the ICRP Committee II on Permissible Dose for Internal Radiation, p. 22. Pergamon Press, Oxford (1959).

9. Loevinger R. and Trott N. G. Int. J. applied Radiat. Isotopes 17, 103 (1966).

10. SUPE S. J. Int. J. applied Radiat. Isotopes 24, 545 (1973).

11. Whitton J. T. Hlth Phys. 24, 1 (1973). 